\title{
ART THINKING AS A CATALYST FOR STEAM STRATEGIES. TOWARDS A DIVERGENT THINKING
}

\author{
V. Santamarina-Campos, M. de-Miguel-Molina, B. De-Miguel-Molina, \\ M.A. Carabal-Montagud \\ Universitat Politècnica de València (SPAIN)
}

\begin{abstract}
Practical training in the university environment, without attention to creativity and innovative thinking, is not very effective. For this reason, we have tried to find a new learning model, which focuses on the disciplines essential for the future, through an interdisciplinary approach.

The use of tools such as Art Thinking and the search for new learning spaces, sometimes outside the classroom and in others transforming the classroom space itself into a "corner to dream", have allowed us to create a conducive climate to the development of creativity and to discover that the combination of technical training with skills associated with the artistic field, are positioned as the ideal way to train the professionals of the future.

Thus, within the strategy of reaching professional competences, it is planned to work jointly and collaboratively between the creative, technological and management disciplines that coexist on the campus of the Universitat Politecnica de Valencia, in the implementation of new training spaces, which favor the acquisition of transversal competences and strengthen the teaching and learning process through visible and responsible learning by means of STEAM strategies.
\end{abstract}

\section{INTRODUCTION. ARTS \& DESIGN COMPETENCE}

Practical training in the university environment, without attention to creativity, design and innovative thinking, is not very effective. As Marcel Just, the Director of the Center for Cognitive Brain Imaging at Carnegie Mellon University, indicated "we were biologically designed to react to visual stimuli and communicate through them". That is we pay more attention to images than to a long text [1]. For this reason, we have tried to find a new learning model that combines STEM areas with artistic disciplines: the STEAM competences. So that the student, through the exercise of design, enhances their flexible thinking and creativity, essential ingredients when it comes to innovating.

The use of tools such as Art Thinking and the search for new learning spaces, sometimes outside the classroom and transforming the classroom into a "corner to dream" [2], have allowed us to create a conducive climate to the development of creativity and to discover that the combination of technical training with skills associated with the artistic field, are positioned as the ideal way to train the professionals of the future.

Thus, within the strategy of reaching professional competences, it is planned to work jointly and collaboratively among the creative, technological and management disciplines that coexist on the campus of the Polytechnic University of Valencia, in the implementation of new training spaces, which favor the acquisition of transversal competences and enhance the teaching and learning process through:

1 A VISIBLE LEARNING through design (collaborative concept maps), where students and teachers become content producers, fostering divergent thinking.

2 A RESPONSIBLE LEARNING, through the incorporation of the SDGs (Sustainable Development Goals) [3] in the subjects involved, promoting awareness of development problems and environmental sustainability among the students, as current and future executors for implementing these objectives.

3 A LEARNING in STEAM, through the combination of artistic and creative skills with STEM education, using practice as a way of acquiring knowledge (reverse pedagogy) and promoting flexible thinking and creativity, essential ingredients when it comes to innovate.

Our goal is to provide the necessary tools to promote problem solving, analysis thinking or team working, providing students with soft skills in both technical and creative profiles in a divergent environment. That is, a solider training for creative professionals with a broader vision. That allows 
them to find multiple answers to the same question, promoting cognitive styles that favor the development of creativity and helping them to build responsible research and innovation projects that meet the SDGs.

Specifically, this work has focused on the design of learning activities linked to the Arts \& Design competence, that is, tasks focused on working on artistic and creative skills that favor divergent thinking, to provide students with tools that allow them find intelligent and innovative solutions to problems and challenges. Therefore, through these practices it is intended to achieve the following transversal competences [4]:

Table 1. Transversal competences linked to the Arts \& Design competence.

\begin{tabular}{|c|c|c|c|}
\hline$T C$ & Domain level ${ }^{1}$ & Indicator & Indicator Arts \& Design \\
\hline $\begin{array}{l}\text { Understanding } \\
\text { and integration }\end{array}$ & $\begin{array}{l}\text { N2 Proceed with logic and } \\
\text { relate and integrate } \\
\text { concepts in complex } \\
\text { situations. }\end{array}$ & $\begin{array}{l}\text { Classify and establish } \\
\text { meaningful } \\
\text { relationships and } \\
\text { differentiate the } \\
\text { causative or } \\
\text { consequential factors of } \\
\text { a fact. }\end{array}$ & $\begin{array}{l}\text { Visual learning, through the } \\
\text { collaborative design of problem trees, } \\
\text { helps to understand causal } \\
\text { relationships (what happens? Why } \\
\text { does it happen?). }\end{array}$ \\
\hline $\begin{array}{l}\text { Applied and } \\
\text { practical } \\
\text { thinking }\end{array}$ & $\begin{array}{l}\text { N3 Design a plan to } \\
\text { address complex situations } \\
\text { individually or in } \\
\text { collaboration with others. }\end{array}$ & $\begin{array}{l}\text { Set / agree on specific } \\
\text { objectives in relation to } \\
\text { the complex situations } \\
\text { that arise. }\end{array}$ & $\begin{array}{l}\text { Visual learning, through the } \\
\text { collaborative design of objective trees, } \\
\text { helps to understand mid-end } \\
\text { relationships (how can it be solved?). }\end{array}$ \\
\hline $\begin{array}{l}\text { Analysis and } \\
\text { problem solving }\end{array}$ & $\begin{array}{l}\text { N3 Solve problems in } \\
\text { teams, in different contexts } \\
\text { and in depth. }\end{array}$ & $\begin{array}{l}\text { Analyze the causes and } \\
\text { effects of problems from } \\
\text { a global approach. }\end{array}$ & $\begin{array}{l}\text { Visual learning, through the design of } \\
\text { collaborative vertical conceptual maps, } \\
\text { produces the best systemic model, } \\
\text { because it synthesizes different points } \\
\text { of view. }\end{array}$ \\
\hline $\begin{array}{l}\text { Design and } \\
\text { project }\end{array}$ & $\begin{array}{l}\text { N2 Plan projects in } \\
\text { collaboration with others. }\end{array}$ & $\begin{array}{l}\text { Base the need of the } \\
\text { project, formulate the } \\
\text { objectives and results } \\
\text { regarding the needs. }\end{array}$ & $\begin{array}{l}\text { The activation of divergent thinking } \\
\text { through a collaborative design exercise } \\
\text { allows to find multiple answers to the } \\
\text { same question, providing creative } \\
\text { solutions. }\end{array}$ \\
\hline $\begin{array}{l}\text { Teamwork and } \\
\text { leadership }\end{array}$ & $\begin{array}{l}\text { N3 Contribute to the } \\
\text { development and } \\
\text { consolidation of the team. }\end{array}$ & $\begin{array}{l}\text { Communicate and } \\
\text { interact contributing to } \\
\text { team cohesion }\end{array}$ & $\begin{array}{l}\text { The collaborative design exercise } \\
\text { produces an understandable design } \\
\text { because everyone participates in the } \\
\text { construction of the model, generating a } \\
\text { feeling of empowerment. }\end{array}$ \\
\hline $\begin{array}{l}\text { Ethical and } \\
\text { professional } \\
\text { responsibility }\end{array}$ & $\begin{array}{l}\text { N3 Show and argue the } \\
\text { relevance of the behaviors } \\
\text { and judgments that are } \\
\text { issued. }\end{array}$ & $\begin{array}{l}\text { Satisfy, through a } \\
\text { dialogue, some need } \\
\text { linked to coexistence } \\
\text { and not discriminating } \\
\text { people. }\end{array}$ & $\begin{array}{l}\text { Visual communication, through } \\
\text { drawing, allows our metal models to be } \\
\text { visual, facilitating dialogue and } \\
\text { removing barriers. }\end{array}$ \\
\hline $\begin{array}{l}\text { Effective } \\
\text { communication }\end{array}$ & $\begin{array}{l}\text { N2 Illustrate the speech to } \\
\text { facilitate understanding. }\end{array}$ & $\begin{array}{l}\text { Reinforce ideas with the } \\
\text { support of media. }\end{array}$ & $\begin{array}{l}\text { Visual Marketing, through drawing / } \\
\text { design, allows an idea to be } \\
\text { communicated more effectively (the } \\
\text { brain processes visual information } \\
60,000 \text { times faster than text). }\end{array}$ \\
\hline Critical thinking & $\begin{array}{l}\text { N2 Analyze whether there } \\
\text { is coherence between own } \\
\text { and other people's } \\
\text { judgments, assessing their } \\
\text { practical implications. }\end{array}$ & $\begin{array}{l}\text { Value the judgments of } \\
\text { others. }\end{array}$ & $\begin{array}{l}\text { The activation of divergent thinking, } \\
\text { through the drawing exercise, brings } \\
\text { clarity, making ideas visible, tangible } \\
\text { and sequential, facilitating the analysis } \\
\text { of different points of view. }\end{array}$ \\
\hline $\begin{array}{l}\text { Lifelong } \\
\text { learning }\end{array}$ & $\begin{array}{l}\text { N3 Develop own learning } \\
\text { strategies. }\end{array}$ & $\begin{array}{l}\text { Design a learning } \\
\text { process to achieve } \\
\text { specific goals. }\end{array}$ & $\begin{array}{l}\text { Visual learning makes the student a } \\
\text { content producer, promoting divergent } \\
\text { thinking. }\end{array}$ \\
\hline
\end{tabular}

\footnotetext{
${ }^{1}$ Master levels: Level 1 (N1), Level 2 (N2) and Level 3 (N3), in relation to the transversal competences of the Universitat Politècnica de València.
} 
In parallel to the acquisition of transversal competences, the proposed practices will allow training in the following sustainable development objectives (figure 1) [3]:

4.- Ensure an inclusive and equitable quality education and promote lifelong learning opportunities for all.

5.- Achieve gender equality and empower all women and girls.

8.- Promote sustained, inclusive and sustainable economic growth, full and productive employment, and decent work for all.

9.- Develop resilient infrastructure, promote inclusive and sustainable industrialization, and encourage innovation.

17.- Strengthen the means of execution and revive the global alliance for sustainable development.

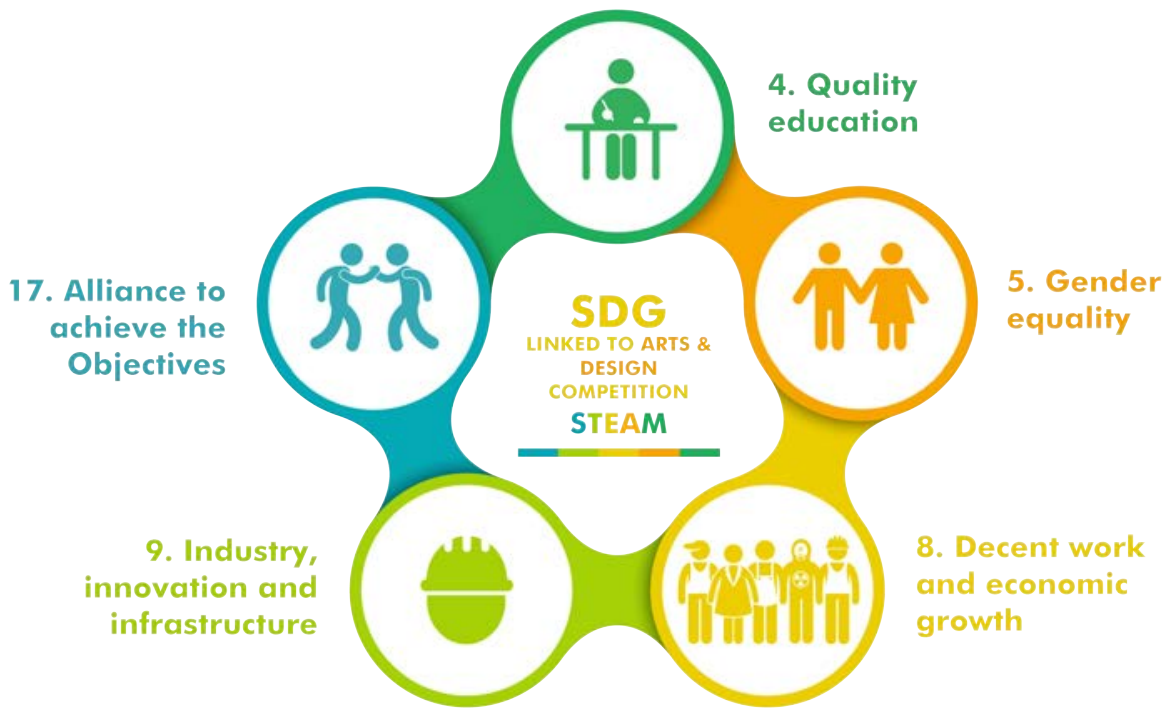

Figure 1. SDGs linked to the learning activities of the Arts \& Design competition. Source: own elaboration from [3].

\section{METHODOLOGY}

The objective of this work is to design and evaluate the impact of learning activities focused on the acquisition of the Arts \& Design competence, so that they can be implemented in STEM education, with the aim of improving scientific-technical education, through the use of learning in STEAM competences.

In addition, the learning tasks will allow the SDGs to work in a simple way through four axes: 1) learning and teaching, 2) research, 3) management and governance, and 4) social leadership, discovering in students the potential of Arts \& Design to achieve the SDGs, fostering awareness of the problems of development and environmental sustainability, as current and future executors and responsible for implementing these objectives.

The learning activities have been implemented in the first semester of the 2019-2020 academic year in subjects related to project management of the master's degree in Conservation and Restoration of Cultural Heritage of the Universitat Politècnica de València. At the end of the subject lessons, students have been sent a test to evaluate the effectiveness of the application of the competence

\subsection{Design of learning activities linked to the Arts \& Design competence}

\subsubsection{Practice 1. DRAW AN IDEA?}

The combination of colored mobile cards (Post-it $\AA$ ) and the visual language to design conceptual maps on large vertical paper formats or on the wall, represents an important change in the 
construction of cooperative models. On the one hand, the use of visual language facilitates making ideas visible, tangible and sequential, and fostering collaborative divergent thinking. On the other hand, the use of color cards allows to assign categories, characterize the processes, etc., and therefore improve the organization and structuring of the maps, since the repetitions are made more fluently. For the realization of this it will be necessary to form a group of 4 students, respecting parity [5].

\begin{tabular}{|c|c|}
\hline \multicolumn{2}{|r|}{ 1st PART } \\
\hline Working model & Individual \\
\hline Material & A3 paper sheet and markers. \\
\hline Description & $\begin{array}{l}\text { Using keywords, represent a process (SIMPLE) that reflects the solution of the } \\
\text { problem posed in the classroom. }\end{array}$ \\
\hline & $\begin{array}{l}\text { The problem can be silvery to students through an image accompanied by a } \\
\text { question that poses a challenge. }\end{array}$ \\
\hline & $\begin{array}{l}\text { The solution must comply with the SDGs. Avoid using phrases. Once finished, } \\
\text { turn upside down and remove them. Work at a distance not to visualize what } \\
\text { other classmates do. }\end{array}$ \\
\hline \multicolumn{2}{|r|}{ 2nd PART } \\
\hline Working model & Individual \\
\hline Material & A3 paper sheet and markers. \\
\hline Description & $\begin{array}{l}\text { Without using words, draw the process described in the previous exercise. Once } \\
\text { finished, turn upside down and remove them. }\end{array}$ \\
\hline \multicolumn{2}{|r|}{ 3rd PART } \\
\hline Working model & Individual \\
\hline Material & A3 paper sheet, markers, Post-it $®$ and scissors. \\
\hline Description & $\begin{array}{l}\text { Without using words, draw the process described in the previous exercise, but } \\
\text { this time using colored mobile cards (Post-it } \AA \text { ), one drawing per card, and these } \\
\text { are placed and organized on a sheet of } A 3 \text { format. You should not seek to } \\
\text { repeat the previous process, it is necessary to forget what is drawn and start } \\
\text { over. }\end{array}$ \\
\hline
\end{tabular}

After finishing the first two steps, the first and the lower row are glued to the wall in the upper row, placing those of each partner in the same column, grouping the qualities that they have analyzed in common. The following questions are launched and discussed in the group:

- Question 1 What do the designs of the 1st, 2nd and 3rd parts have in common? What elements do the designs contain?

- Question 2 What do represent the nodes? What do represent the links?

- Question 3 What is the difference among the designs of the 1st, 2nd and 3rd part?

\begin{tabular}{|l|l|}
\hline \multicolumn{2}{|l|}{ 4th PART } \\
\hline Working model & Group (Parity) \\
\hline Material & Continuous paper, markers, colored Post-it@ and scissors. \\
\hline Description & $\begin{array}{l}\text { Starting from the maps made in the 3rd part, the process is repeated by reusing the } \\
\text { cards, but this time working in a group. The exercises are placed on the continuous } \\
\text { paper or wall to facilitate the reuse of the cards. }\end{array}$ \\
\hline
\end{tabular}

After completing the exercise, the resulting diagram is analyzed. The following questions are launched and discussed in a group: 
- Question 4 What is the difference between the exercise 2nd and 3rd?

\subsubsection{Practice 2 and 3. Do we design trees?}

The design technique of the problem tree and the objectives for the conceptualization of innovative ideas, in the form of diagrams of a negative situation with causes and effects and "half-end" relationships, is an analytical and flexible tool that enhances the commitment, transparency, structuring and participation [5].

These practices have the objective of showing the capacity of analysis provided by the problem tree and the objective design technique, to mature innovative ideas in a collaborative way, and to build responsible research and innovation projects that comply with the SDGs.

For the realization of them it will be necessary to form a group of between 3 or 5 students, respecting parity.

\begin{tabular}{|c|c|}
\hline \multicolumn{2}{|r|}{ 1st PART DESIGN PREPARATION } \\
\hline Working model & Group (Parity) \\
\hline Material & Continuous paper, markers, colored Post-it $\circledast$ and scissors. \\
\hline \multirow[t]{4}{*}{ Description } & $\begin{array}{l}\text { 1st. A problem is posed to students through an image or a short text (maximum one page) } \\
\text { that describes a negative situation to solve. This situation will include aspects related to the } \\
\text { SDGs. }\end{array}$ \\
\hline & $\begin{array}{l}2 \text { nd. Continuous paper or a format bigger than A3 is prepared, preferably placing it on the } \\
\text { wall. }\end{array}$ \\
\hline & $\begin{array}{l}\text { 3rd. Each participant must take a Post-it@ package, all of the same color. On each card, } \\
\text { you will individually write or draw a problem related to the problem to solve. It is very } \\
\text { important to write / draw a single problem per card and use the minimum number of } \\
\text { possible words or simple drawings. The cards are pasted on the paper, without following } \\
\text { any specific order. It is important that this first task will be done individually, without } \\
\text { comments among the team. }\end{array}$ \\
\hline & $\begin{array}{l}\text { 4th. Once all the problems have been identified individually, a discussion is carried out, in } \\
\text { which the problems identified by each one are presented and discussed in a respectful } \\
\text { manner. In case of coinciding in the identification of problems, the repeated cards will be } \\
\text { eliminated. }\end{array}$ \\
\hline \multicolumn{2}{|r|}{ PART 2 PROBLEM TREE } \\
\hline Working model & Group (Parity) \\
\hline Material & Continuous paper, markers, colored Post-it $\circledast$ and scissors. \\
\hline \multirow[t]{4}{*}{ Description } & $\begin{array}{l}\text { Once everyone knows the perception of the problem by the others, we will proceed to order } \\
\text { all the needs detected in a problem tree, starting from the identification of the focal problem } \\
\text { and ordering the rest of the problems according to their cause and effect relationship. For } \\
\text { the organization of the problems, different colors of Post-it } 囚 \text { can be used to rank and } \\
\text { organize the tree. To build the problem tree, proceed as follows: }\end{array}$ \\
\hline & $\begin{array}{l}\text { 1st. First, the main existing, and not possible, imagined or future problems will be identified. } \\
\text { Formulations such as the absence of a solution must be avoided and characterized as an } \\
\text { existing negative state. }\end{array}$ \\
\hline & $\begin{array}{l}\text { 2nd. Secondly, a focal problem must be selected and agreed among all those identified. } \\
\text { The focal problem must clearly describe the essence of a general situation that is } \\
\text { considered unsatisfactory. To decide what is the central problem among those selected as } \\
\text { possible focal points, a brief consideration should be made, and an agreement must be } \\
\text { reached. If there is no consensus, you can try to order all the central problems proposed up } \\
\text { and down according to the causes and effects, to try to identify the focal point. If this is not } \\
\text { possible, one or several central problems must be temporarily adopted. It is important to } \\
\text { remember that the central problem does NOT always automatically become the main } \\
\text { objective of the project. }\end{array}$ \\
\hline & $\begin{array}{l}\text { 3rd. Third, the problem tree will be developed (figure 2). This task is to identify the } \\
\text { substantial and direct causes and effects of the focal problem. Thus, from all the problems } \\
\text { identified, a tree that reflects the cause-effect relationships between the problems is } \\
\text { constructed. In this task, cooperation will be essential, both in the design and in the revision } \\
\text { of the tree, to ensure that it is valid and complete, making the necessary adjustments. }\end{array}$ \\
\hline
\end{tabular}




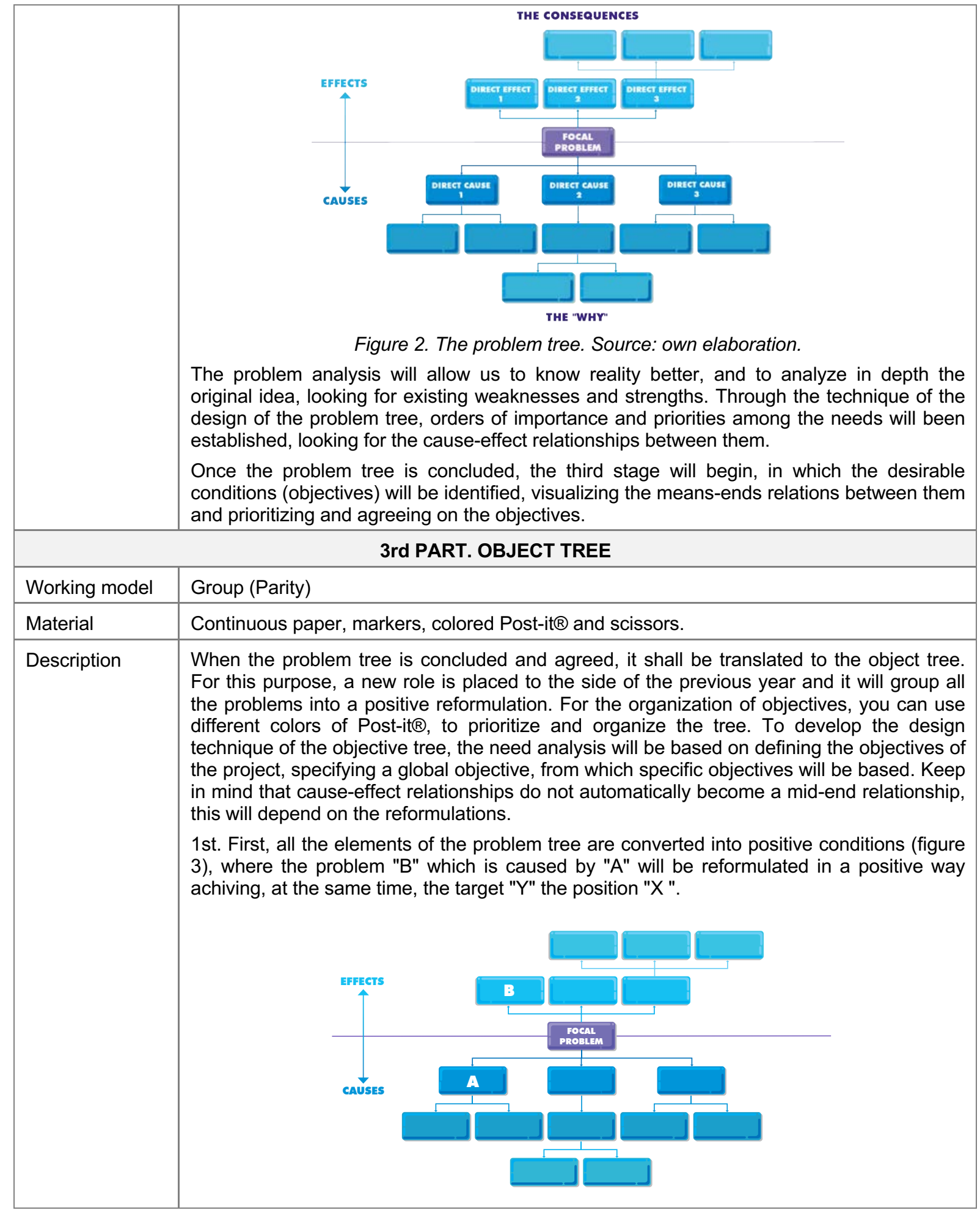




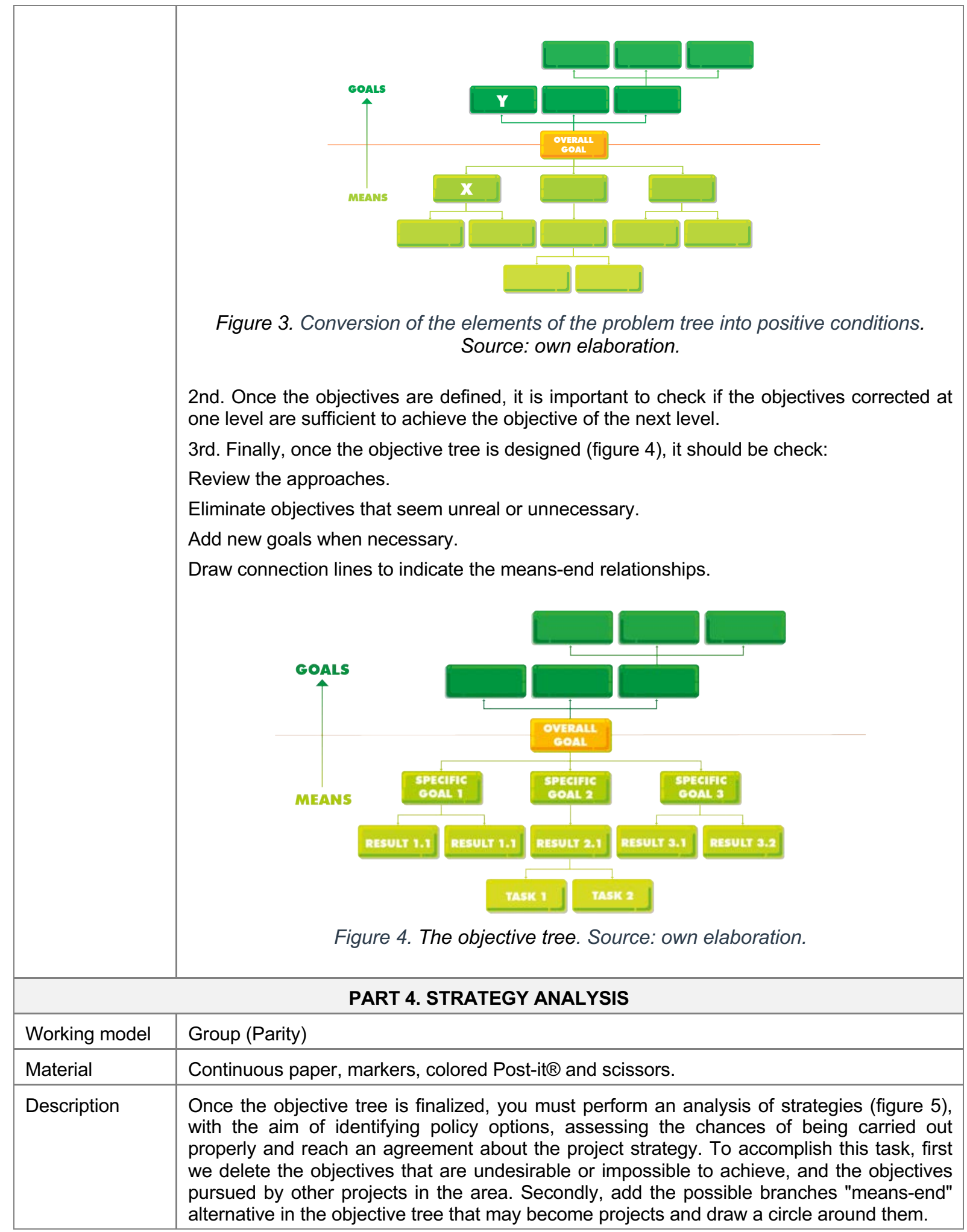




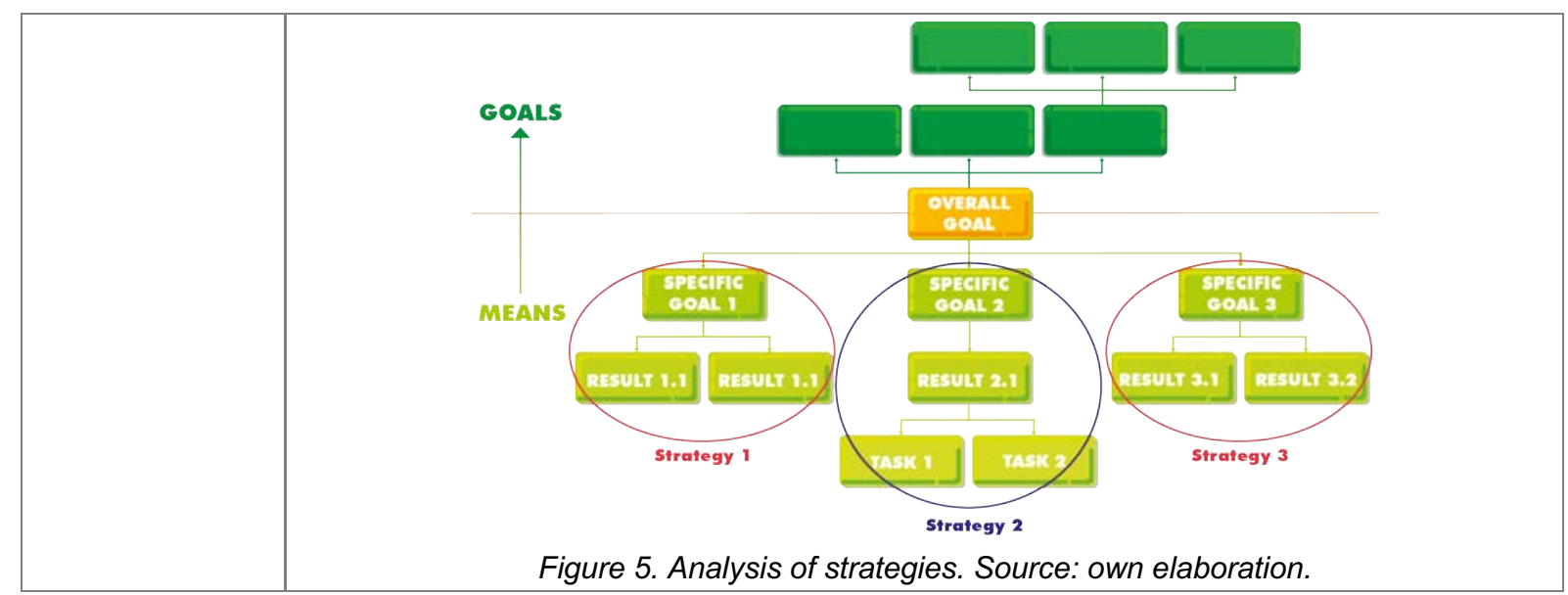

\subsection{General questions to students to assess whether they apply the competence}

At the end of each semester, the students will be given a brief questionnaire to show that the strategy we wanted to teach has been internalized. If the results are positive, this project can be extended to other master program subjects or even to other degrees that use STEM education and have not yet incorporated the Arts \& Design competence, becoming STEAM.

Arts \& Design competence assessment test:

1 Does drawing and design make it easier to find solutions to the problems raised?

2 Does drawing and design make it easier to come up with something new and materialize it?

3 Do real cases analyzed through manipulative and collaborative practices (for example, with Post-it colors, color stickers, large paper formats, colored markers ...), provide useful tools to solve problems?

4 By developing collaborative concept maps using drawings, keywords and mobile cards, can you find multiple answers to the same question?

5 Does design and draw in group contribute to creativity and finding innovative solutions?

6 Does group collaborative design make it easier to synthesize different points of view?

7 Does transform the classroom space (modify the distribution of furniture, use the walls, etc.) contribute to the development of creativity?

8 Does transform the classroom space (modify the distribution of furniture, use the walls, etc.). favor teamwork?

\section{RESULTS}

In the subjects in which the Arts \& Design competence has been implemented, we have been able to verify that it has favored divergent thinking, making students find innovative solutions to the problems and challenges posed in an agiler way. It has been possible to perceive two important changes:

- 1st. It has facilitated and streamlined the analysis capacity and the resolution of the problems raised in the classroom, being able to increase the number of practices carried out during the semester by $15 \%$, demonstrating the potential of drawings and designs, since the human brain can process entire images that the eye sees for only 13 thousandths of a second [7].

- 2nd. The transformation of the classroom space to enhance divergent thinking has been reflected in greater creativity, increasing the number of solutions for the problems by up to $25 \%$, in relation to other courses. 


\section{CONCLUSIONS}

This experience has shown us that the implementation of the Arts \& Design competence has significantly helped students to find intelligent solutions to the problems and challenges posed. In relation to the implementation of the tasks related to the Arts \& Design competence, it has become clear that the classrooms currently available at the university do not favor divergent thinking, and this is a great effort for both teachers and students when adapting these spaces in "corners to dream". There is an imperative need in relation to the transformation of traditional classrooms into more friendly, flexible and creative spaces that facilitate the implementation of STEAM learning, creativity and innovative thinking.

\section{ACKNOWLEDGEMENTS}

This work has been developed within the project "Applying STEAM strategies in the Social Sciences and Arts areas by means of a Service-learning methodology", conducted by Professor María deMiguel-Molina, and with the support of the Universitat Politécnica de València (Science Education Institute, ICE).

Moreover, this paper's authors belong to the team 'Reality baths: towards a visible, responsible and innovative learning', coordinated by Professor Virginia Santamarina-Campos.

\section{REFERENCES}

[1] M. Just, L. Melissa, "Watching the Human Brain Process Information-Nieman Reports", Nieman Reports, 2010. Retrieved from https://niemanreports.org/articles/watching-the-human-brainprocess-information/

[2] E. Punset, "Redes- La mirada de Elsa: La creatividad",RTVE.es, 2013. Retrieved January 9, 2020, from http://www.rtve.es/alacarta/videos/redes/redes-mirada-elsacreatividad/1643868/\#aHR0cDovL3d3dy5ydHZILmVzL2FsYWNhcnRhL2ludGVybm8vY29udGVu dHRhYmxILnNodG1sP2N0eD0xNzA1JmxvY2FsZT1IcyZwYWdIU2I6ZT0xNSZzZWN0aW9uRmls dGVyPTU5NDMwJmFkdINIYXJjaE9wZW49ZmFsc2U=

[3] United Nations, "Sustainable Development Goals", 2019. Retrieved from https://www.un.org/sustainabledevelopment/.

[4] Universitat Politècnica de València, "Competencias Transversales", 2019. Retrieved from http://www.upv.es/contenidos/COMPTRAN/index-en.html.

[5] V. Santamarina, M.Á. Carabal, M.de Miguel, B. de Miguel, "Collaborative Visual Language for the Development of Innovative Ideas", EDULEARN18 Proceedings, pp. 535-543. 2018a.

[6] V. Santamarina, M.Á. Carabal, M. de Miguel, B. de Miguel, "From the Idea To the Project. Collaborative Trees As an Analytical Tool", EDULEARN18 Proceedings, pp. 517-528. 2018b.

[7] M.C. Potter, B. Wyble, C.E. Hagmann, E.S. McCourt (2014). Detecting meaning in RSVP at 13 ms per picture. Attention, Perception, and Psychophysics, 76(2), 270-279.

https://doi.org/10.3758/s13414-013-0605-z 